Apidologie, 1981, 12 (2), 113-123.

\title{
FOOD REQUIREMENTS OF CAGED HONEY BEES (*)
}

\author{
B. F. DETROY, L. O. WHITEFOOT and F. E. MELLER
}

Agricultural Engineer, Mechanical Engineering Technician and former Research Leader, respectively, Bee Research Laboratory, Agricultural Research-Science and Education Administration, U.S. Department of Agriculture, Madison, Wisconsin 53706.

\section{SUMMARY}

Caged honey bees held in a constant environment $\left(62 \pm 5^{\circ} \mathrm{F}\right)$ were subjected to five nutritional regimes, and their mortality rates were determined. Mean survival was 85 percent or higher for all treatments after 6 days of confinement. Sugar syrup was the most satisfactory of the treatments used in this study. Parcel post shipments of bees in packages without food were entirely satisfactory for in-transit time of 38 hours but were questionable when the in-transit time was extended to 90 hours.

\section{INTRODUCTION}

Providing the food and water necessary to ensure successful shipment of packaged honey bees (Apis mellifera $\mathrm{L}$.) has always been a problem. Combs of honey were used for food in the prepackaging era when bees were shipped in full colonies or as nuclei. This practice was largely discontinued as the demand for the shipment of bees from the South to the North increased and the use of combless packages became common practice. Considerable effort has been expended in investigating the nutritional adequacy of various carbohydrate formulations for packaged bees from the time the package is made up until it is installed in a new hive.

When bees were first shipped without combs, a soft candy was used as feed. Use of the candy was not satisfactory because it did not provide the moisture required by the bees and it dried too rapidly. Komarow and Alpatov (1935) found that colon Madison.

$\left.{ }^{*}\right)$ In cooperation with the College of Agricultural and Life Sciences, University of Wisconsin- 
gorging causes restlessness in bees but that honey-sac filling prolongs the possible time of confinement without food. Thus, they recommended the use of a thick sugar syrup (67\% sugar) for the shipment of bees because it outlasts thin syrup ( $33 \%$ sugar).

Of the several superfluous types of food for packaged bees that have been tried, the most successful and the one now used almost exclusively is sugar syrup. DaDANT (1927) determined that 1 pint of sugar syrup should feed a 3-pound package of bees for a 5-day trip in ordinary weather. Usually, a feeder tin containing the syrup is placed in the shipping container, and the liquid is dispensed to the bees by the vacuum principle. The greatest disadvantages of sugar syrup are the added shipping cost due to the weight of the container and the leakage during shipment. A feeder can with a special valve mechanism for dispensing syrup to packaged bees was designed by EGGERS (1933) in an attempt to reduce the leakage. More recently a committee of Postal Service and industry representatives made a survey of the problems concerned with the postal shipment of packaged bees. Menashes (1971) reported on the findings of this committee and listed one of the serious problems as the leakage of liquid bee food and its effects on the operation of postal equipment, as well as its contamination of mail.

Shipment with some food other than sugar syrup, or without food, could be advantageous. McDougaLl (1936) trucked a load of packaged bees from the State of Mississippi to Manitoba, Canada, without feeder cans. Bees in the packages were fed sugar syrup before the packages were loaded and they were fed once enroute. The trip took 5 days and the bees arrived in good condition. Once, a shipment of packaged bees in which the feeder can had been inadvertently left out of the shipping package was received at the Bee Research Laboratory. The bees were in excellent condition upon arrival. Thus, shipment of bees without food appears possible if the shipping time is limited.

These considerations and the consideration of designing a shipping container that would also serve as a satisfactory disposable pollination unit posed questions about the quantity of food necessary, the type of food most suitable, and how the food could best be provided. To obtain information in addition to that found in the literature, we investigated the food requirements of packaged bees. The problem was investigated by feeding packages of bees in storage and by shipping packaged bees with and without food.

\section{MATERIALS AND METHODS}

\section{Feeding Tests}

Screened cages similar in size and shape to standard shipping containers for packaged bees were used for the feeding tests. The cage design allowed removal of the dead bees on a regular basis. Provisions were also made to provide food and water for the bees. 
Each cage was stocked with approximately 2 pounds $(0.907 \mathrm{~kg})$ of bees and a caged, mated queen. All bees and queens were of the same genetic stock. Some drones were present when the bees were collected from colonies for use in the tests and an attempt was made to have them evenly distributed among the cages. The feeding tests were begun on the same day the bees were removed from colonies. All cages with bees were placed in random order on a rack inside a completely dark room where the temperature was maintained at $62 \pm 5^{\circ} \mathrm{F}\left(16.7 \pm 2.8^{\circ} \mathrm{C}\right)$.

The treatments were as follows : (1) no food, but water supplied, (2) no food or water supplied, (3) solid fondant (candy), only supplied, (4) initial forced engorgement with sugar syrup spray and no food or water supplied thereafter, and (5) sugar syrup fed. Each treatment was replicated four times, making a total of 20 packages of bees. The total weight of bees in each cage was recorded at the beginning of the test and the number of bees per cage was estimated by the 100 -bee-sample-weight method. In this method, a counted 100-bee-sample from the mass is weighed to determine the average weight per bee. Then the entire mass of bees is weighed and the total weight is divided by the average weight per bee. The resulting value gives a close estimate of the total number of bees in the mass.

The water and sugar syrup were fed to the bees by placing inverted, filled vials covered with cheesecloth on the cages in direct contact with the screen. Forced engorgement of the bees was provided for by spraying the sugar syrup directly on the bees through the screen. All sugar syrups used were $1: 1(\mathrm{v} / \mathrm{v})$ mixtures of sugar and water. Solid food was fed in a plastic cup suspended inside the cage. All cages for which food was supplied received the same amount of sugar by weight, whether as syrup or as solid food. The solid fondant food treatment was made up of two replicates, each, of two materials. On material was Drifond $\left(^{*}\right)$ which was a mixture of dry sugar, invert sugar and water; and the other was Wetfond, which was a commercially available, semisolid invert sugar material. Dead bees were removed from the cages at 2-day intervals and counted. The tests were terminated after 13 days and the number of live bees remaining in each cage was determined. Differences in the mean mortality of bees for all treatments after both 4 and 6 days of confinement were compared by analysis of variance using the Student-Newman-Keuls' (S.N.K.) test.

\section{Package Shipments}

Two shipments of packaged bees were made in which the feeder cans were purposely left out of some packages, but the remaining packages were provided with sugar syrup. The package shippers were asked to shake all packages in the usual manner and to handle them normally in the pre-shipment period. The only difference in preshipment preparation was to be the omission of the feeder cans in some of the shipping packages.

One shipment of 15 packages was made from Mayhew, Mississippi to Madison, Wisconsin during the last week of April. All packages contained 2 pounds $(0.907 \mathrm{~kg})$ of bees with queens. Information received indicated that the bees were collected from colonies in the late forenoon, placed in a cool room at 2:00 pm, and held until mailing time at 6:30 pm. The packages were sent parcel post, with special handling and insured. Ten of the packages were shipped without feeder cans. The packages arrived at their destination 38 hours after they were shipped.

The second shipment, consisting of 50 packages, was made from La Belle, Florida to Madison, Wisconsin during the last week of May. All were 2-pound $(0.907 \mathrm{~kg})$ packages, with queens and were shipped parcel post, with special handling and insured. Fifteen of the packages were shipped without feeder cans. No information on the collection or handling of the packages before shipment was received; however, the shipping date was indicated by the postmarks. The packages arrived at their destination early on the fourth day after they were shipped.

The condition of all packages in both shipments was evaluated upon their arrival at destination. Then sugar syrup was sprayed on the bees so they could feed until gorged.

(*) Reference to a company or product name is for specific information only and does not imply approval or recommendation of the product by the U.S. Department of Agriculture to the exclusion of others that may be suitable. 


\section{RESULTS AND DISCUSSION}

The percentage of bee mortality for each replicate of the feeding test is presented graphically in figure 1. After the tests had been in progress 4 days the maximum total loss of bees in any cage was 10.7 percent and that loss was in a package that had

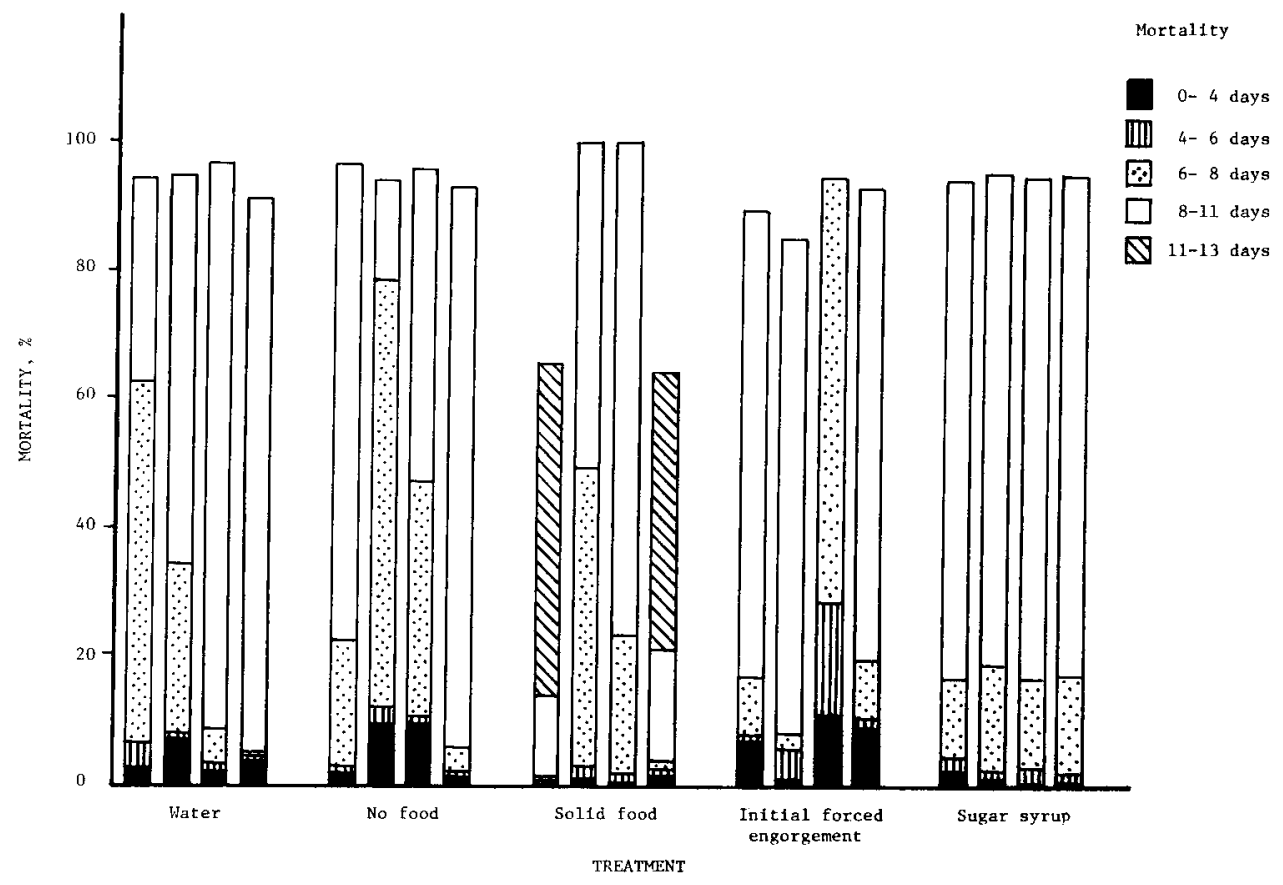

FIG. 1. - Cumulative percentage of mortality for caged honey bees fed five diets, 4 treatments per diet.

received initial direct spraying with sugar syrup, but no additional food or water thereafter. During the first 4 days of confinement there were also total losses of 9.3 and 9.6 percent, respectively, in two cages in which no food was provided. After 6 days of confinement, bees in only one cage had a total mortality greatly in excess of 10 percent and those bees had received the initial forced-engorgement treatment. Mortality during the 4- to 6-day interval was generally small.

Drones were the first bees to die in all treatments. The drones died during the first 4 days in the no-food, the water, and the forced engorgement treatments. In the other two treatments most of the drones died between the sixth and eighth day of confinement.

A considerable difference was noted between the percentages of mortality with the two materials used in making up the solid fondant food. Based on mortality rates the semisolid invert sugar material, replicates 2 and 3 of the solid fondant treatment in 
Figure 1, was effective up to 6 days, whereas the mixture of dry sugar, invert sugar and water, replicates 1 and 4 of the solid fondant treatment in Figure 1, was effective for 8 days and had less than 25 percent loss of population after 11 days of confinement. Therefore, the composition of the solid fondant food is apparently important.

Figure 2 presents the treatment means for mortality shown after 2,4 and 6 days of confinement, along with the range of mortality for each time period. The range of

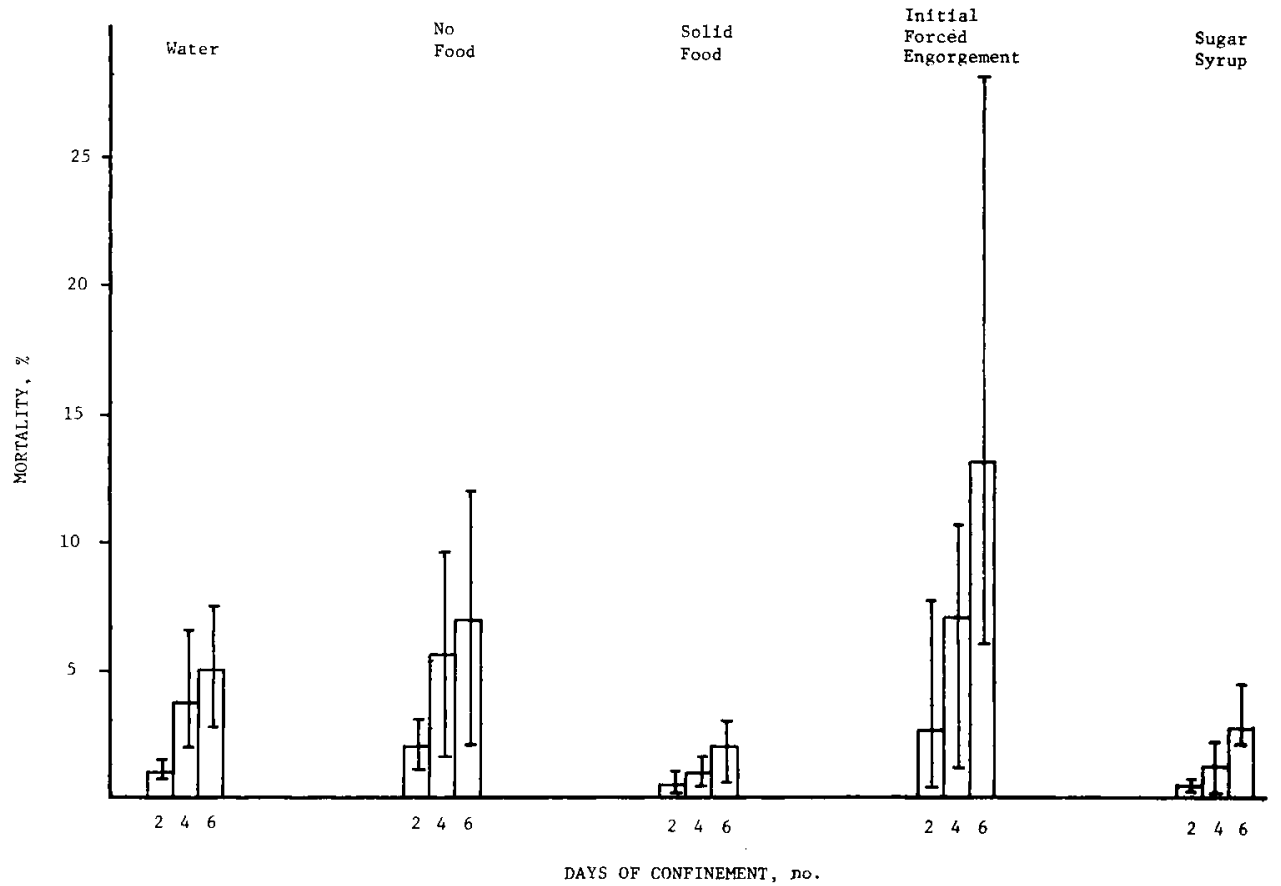

FIG. 2. - Mortality of caged honey bees expressed as treatment means for five feeding treatments and indicating the range within each treatment.

mortality within the solid food and sugar syrup treatments was slight, even after 6 days, whereas, in all other treatments variability was much greater, particularly the one that provided for initial forced engorgement. In two of the replications of the treatment in which water was fed continuously, mortality was less than 10 percent over the first 8 days, but in the other two replications mortality was high between the sixth and eighth days. Thus, only a slight weight advantage would be gained by using water over sugar syrup as food; however, the damage caused by water spillage in transit could be considerably less than that caused by sugar syrup. The shipping cost advantage would likely be appreciable only for the no-food and the gorging treatments.

All packages shipped from Mississippi to Wisconsin via parcel post arrived in excellent condition. No distinction could be made between the number of dead bees in 


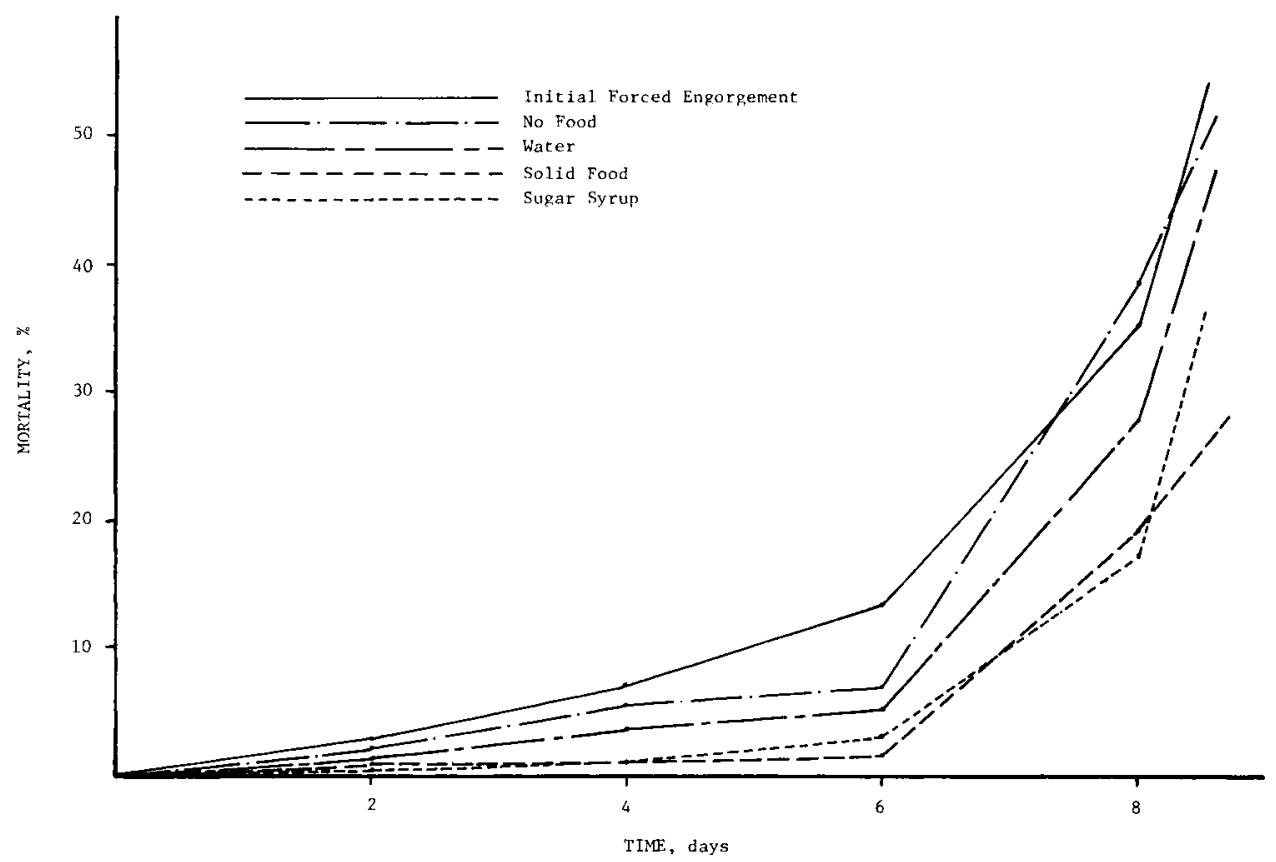

Fig. 3. - Mortality of caged honey bees by treatment. Plotted values are means of four replications.

the packages in which no food was provided and in those in which the standard sugar syrup feeder cans were provided (Fig. 4 and 5).

In the shipment from Florida to Wisconsin all packages containing sugar syrup feeder cans were in good condition and contained few dead bees (Fig. 6); the maximum was approximately 10 percent. Nine of the 15 packages shipped without food were in good condition; in two, about 25 percent of the bees were dead; in two, about 75 percent were dead and in two, all bees were dead (Fig. 7). Shipping costs could not be compared because the packages with feeder cans and those without were mixed in the crates of three packages each. This shipment was apparently in transit about the maximum time possible. In several of the packages in which bees were down, we were able to revive them by forced engorgement of sugar syrup. This shipment was also made late in the season, when warm temperatures made a long confinement period without food or water particularly unfavorable.

A statistical analysis of the data, based on bee mortality, indicated no difference in results of any of the feeding treatments after 2 days. Table 1 data indicate that after 4 days the percentage of mortality for the forced engorgement treatment and the solidfood and sugar syrup treatments differed significantly at the 0.10 level. This result indicated that the forced engorgement treatment was of questionable value after 4 days of confinement when compared to results from the other treatments used. After 


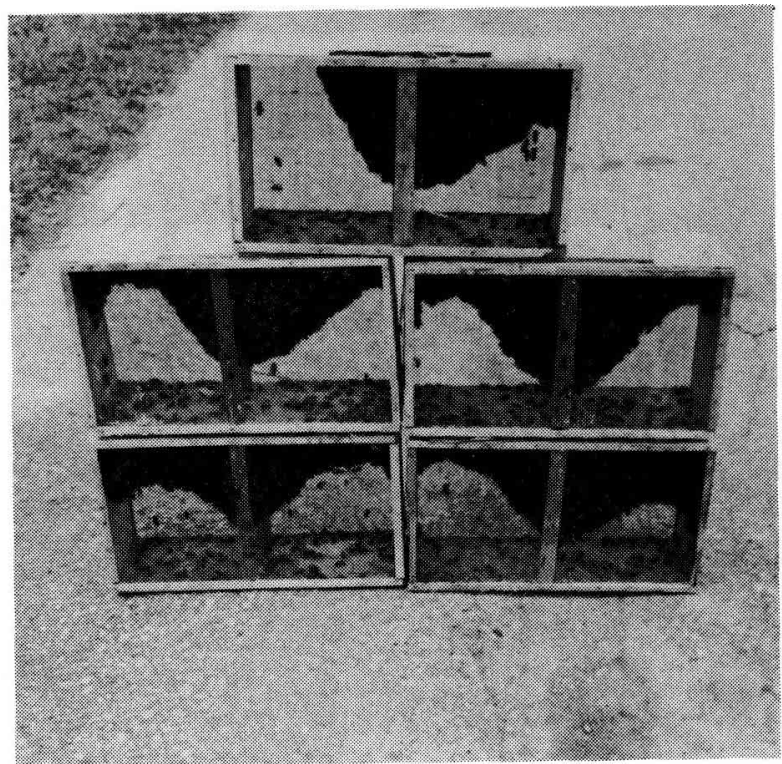

FIG. 4. - Arrival condition of packaged bees shipped via parcel post from Missississippi to Wisconsin, with feeder cans of sugar sirup. As indicated, few bees were dead.

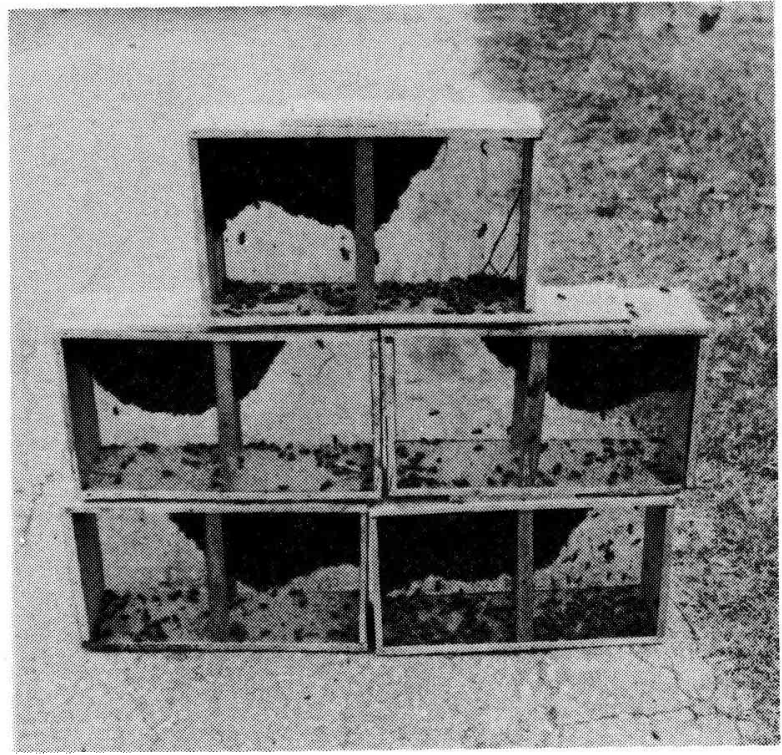

Fig. 5. - Arrival condition of packaged bees shipped via parcel post from Mississippi to Wisconsin without food.

Note that the number of dead bees was about the same as when food was provided (Fig. 4). 


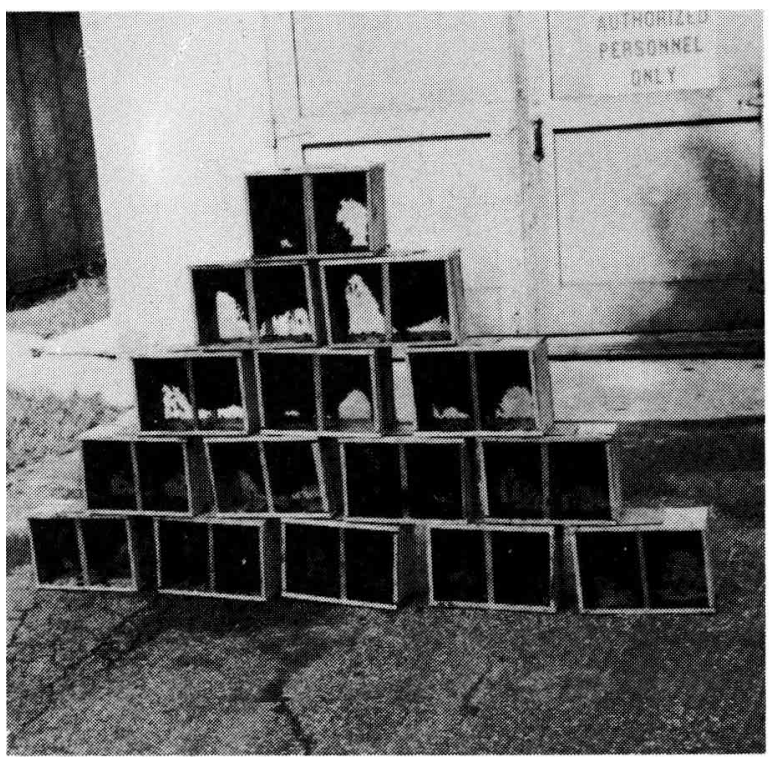

Fig. 6. - Arrival condition of packaged bees shipped via parcel post from Florida to Wisconsin, with feeder cans of sugar sirup. Dead bees visible did not appear excessive.

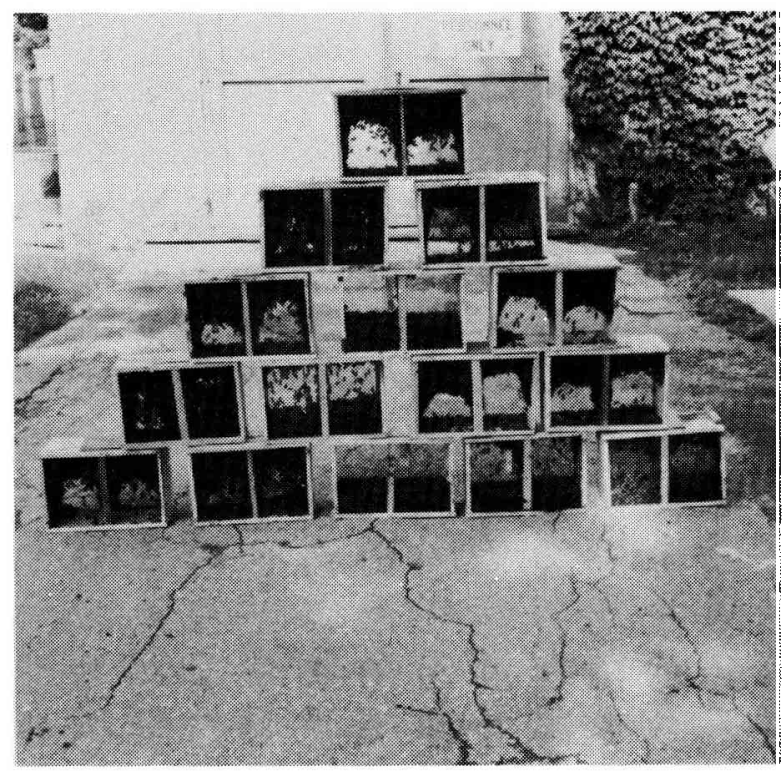

FIG. 7. - Arrival condition of packaged bees shipped via parcel post from Florida to Wisconsin without food.

Dead bees had accumulated in the bottom of some cages. 
TABL. 1. - Percentage of honey bee mortality, by treatment, after 4 days of confinement (*)

\begin{tabular}{c|l|l|l|c}
\hline \hline Solid food & Sugar syrup & Water & No food & $\begin{array}{c}\text { Initial } \\
\text { gorging }\end{array}$ \\
\hline 0.4 & 2.2 & 2.4 & 1.7 & 7.2 \\
0.4 & 2.2 & 2.4 & 7.2 & 1.1 \\
1.1 & 1.0 & 6.6 & 9.3 & 10.7 \\
0.5 & 0.3 & 1.9 & 9.6 & 9.0 \\
1.7 & 0.8 & 3.5 & 1.3 & $7.00 \mathrm{~b}$ \\
\hline $\mathrm{x} 0.93 \mathrm{a}$ & $1.08 \mathrm{a}$ & $3.60 \mathrm{ab}$ & $5.48 \mathrm{ab}$ & \\
\hline \hline
\end{tabular}

(*) Means followed by different letters are significantly different at the 0.10 level, according to Student-Newman-Keuls'test.

6 days the percentage of mortality among bees that received the no-food treatment was also significantly different, at the 0.10 level, from that of bees that received the sugar syrup and solid-food treatments. Despite these significant differences in mortality rates, the mean percentage of dead bees was low enough, after 6 days of confinement, for all treatments to be considered acceptable. When confinement had exceeded 6 days, the rate of bee mortality began to rise sharply in all treatments (Fig. 3).

\section{CONCLUSIONS}

Packaged bees were placed in a room, held at constant environment and subjected to 5 nutritional regimes to determine their food requirements based on mortality. Packaged bees were shipped with and without food and evaluated upon arrival at their destination.

Results of this study indicated that :

1. Sugar syrup was consistently the best food for containerized bees.

2. Providing water with no food had no beneficial effect at constant temperature of $62 \pm 5^{\circ} \mathrm{F}\left(16.7 \pm 2.8^{\circ} \mathrm{C}\right)$.

3. The particular invert sugar used in producing the solid fondant food had a specific effect on acceptability of the sugar for containerized bees.

4. Drones were the first to die in cages of bees, regardless of treatment.

When bees are shipped at constant temperature of $62^{\circ} \pm 5^{\circ} \mathrm{F}\left(16.7 \pm 2.8^{\circ} \mathrm{C}\right)$ and are not disturbed, 90 percent of the bees in a container (package) should survive through 6 days of confinement, even without food. Actual parcel post shipping time for bees shipped in packages without food would have to be restricted to less than 4 days to ensure good arrival condition. Transit time for packages without food could be extended to 4 days or more if temperature could be maintained between $60^{\circ}$ and $70^{\circ} \mathrm{F}\left(15.6^{\circ}\right.$ and $\left.21.1^{\circ} \mathrm{C}\right)$ and relative humidity above $50 \%$. 
Further experimentation is needed regarding the effectiveness of different invert sugar formulations of solid food for use in packaged bee shipments. Actual shipments of bees in packages without food for which preshipment handling, actual in-transit time, in-transit environmental conditions and postshipment condition are closely monitored would provide valuable information to the industry. Parcel post shipments, shipments by commercial trucks, and, possibly, air shipments should be studied.

Received for publication in November 1980.

\section{RÉSUMÉ \\ LES BESOINS ALIMENTAIRES DES ABEILLES ENCAGÉES}

On a soumis des paquets d'abeilles, composés de $0,9 \mathrm{~kg}$ d'ouvrières et d'une reine et placés dans une pièce aux conditions de milieu constantes, à 5 régimes alimentaires afin de déterminer leurs besoins nutritionnels d'après la mortalité : eau seule; ni eau, ni nourriture; candi; gavage initial par pulvérisation de sirop de sucre puis plus aucune nourriture; sirop de sucre. Les paquets d'abeilles ont été expédiés avec ou sans nourriture et estimés à leur arrivée. Il s'agissait avant tout de savoir s'il était possible d'expédier des abeilles sans nourriture, car cela permettrait d'éviter des difficultés certaines (nourriture qui coule, poids).

Les résultats de cette étude montrent que :

1. Le sirop de sucre est assurément la meilleure nourriture pour des abeilles encagées.

2. La fourniture d'eau non accompagnée de nourriture n'a aucun effet bénéfique à la température constante de $16,7 \pm 2,8^{\circ} \mathrm{C}$.

3. La différence dans les résultats obtenus avec deux candis du commerce prouve que le sucre inverti spécial utilisé pour faire le candi a une action spécifique sur l'acceptabilité du sucre par les abeilles encagées.

4. Quel que soit le régime alimentaire, les mâles sont les premiers à mourir en cage.

Lorsque les abeilles sont expédiées à la température constante de $16,7 \pm 2,8^{\circ} \mathrm{C}$ sans être perturbées, $90 \%$ des abeilles d'une cage survivent pendant 6 jours, même sans nourriture. La durée réelle de transport en paquet poste d'abeilles sans nourriture devrait être réduite à moins de 4 jours pour garantir de bonnes conditions à l'arrivée. La durée de transport pour des paquets d'abeilles sans nourriture peut s'étendre à 4 jours ou plus à condition que la température soit maintenue entre 15,6 et $21,1^{\circ} \mathrm{C}$ et que l'humidité relative soit supérieure à $50 \%$.

D'autres expériences sont nécessaires concernant l'efficacité des divers sucres invertis entrant dans la préparation de candis à utiliser dans les expéditions de paquets d'abeilles. Des expéditions réelles d'abeilles en paquets sans nourriture, pour lesquelles on contrôlerait avec précision les manipulations avant l'envoi, le temps réel de transport, les conditions de milieu pendant le transport, fourniraient à l'industrie une information valable. Il faudrait étudier les expéditions par poste, par transporteurs routiers et si possible par avion.

\section{ZUSAMMENFASSUNG}

\section{DER FUTTERBEDARF VON GEKÄFIGTEN BIENEN}

Bienenpakete (Kunstchwärme mit $0,91 \mathrm{~kg}$ Bienen und Königin) wurden in einem Raum unter konstanten Bedingungen gehalten und nach fünf verschiedenen Methoden ernährt (Wasser allein, ohne jedes Futter, Zuckerteig, erzwungene Futteraufnahme durch Besprühen mit Sirup vor dem Versand, 
Zuckersirup), um ihren Futterbedarf zu bestimmen. Als Bewertungsmasstab diente die Mortalität. Ausserdem wurden Paketbienen mit und ohne Futter versandt und bei ihrer Ankunft bewertet. Es ging vor allem um die Frage, ob ein Versand ohne Fütterung möglich ist, weil dadurch gewisse Schwierigkeiten vermieden werden könnten (Ausrinnen des Futters, Gewicht).

Die Ergebnisse der Untersuchung lassen folgendes erkennen :

1. Zuckersirup ist eindeutig die beste Nahrung für gekäfigte Bienen.

2. Die Versorgung mit Wasser ohne Futter brachte keinen Vorteil bei konstanter Temperatur von $16,7 \pm 2,8^{\circ} \mathrm{C}$.

3. Die unterschiedlichen Resultate mit zwei kommerziell erzeugten Zuckerteigen sprechen dafür, dass der spezielle Invertzucker, der für die Erzergung des festen Zuckerteigs verwendet wird, einen eigenen Effekt auf die Verwertung des Zuckers durch die gekäfigten Bienen hat.

4. Die Drohnen starben in den Bienenkäfigen zuerst, ungeachtet der Art der Fütterung.

Wenn Bienen bei konstanter Temperatur von $16,7 \pm 2,8^{\circ} \mathrm{C}$ versandt und wenn sie dabei nicht beunruhigt werden, sollten $90 \%$ der Bienen in der Versandkiste 6 Tage überleben, selbst wenn sie in dieser Zeit nicht gefüttert werden. Für den tatsächlichen Versand ohne Futter mit der Paketpost muss die Transportzeit aber auf weniger als 4 Tage beschränkt werden, um einen guten Zustand bei der Ankunft zu gewährleisten. Könnte die Temperatur zwischen 15 und $21^{\circ} \mathrm{C}$ und die relative Luftfeuchte über $50 \%$ gehalten werden, dann wäre es möglich, die Transportzeit für Bienenpakete ohne Futter auf vier Tage und mehr auszudehnen.

Es sind weitere Versuche erforderlich über die Wirkung von verschiedenen Arten von Invertzucker, die für die Bereitung des Zuckerteiges benutzt werden. Konkrete Versuche mit dem Versand von Paketbienen ohne Futter, bei denen die Behandlung vor dem Versand, die tatsächliche Transportzeit, die Umgebungsbedingungen während des Transportes und nach dem Transport sorgfältig kontrolliert werden, könnten wertvolle Informationen für die Bienenwirtschaft liefern. Es sollten der Versand mit der Paketpost und mit Lastwagen-Transportfirmen und wenn möglich auch mit Luftfracht untersucht werden.

\section{REFERENCES}

Dadant M. G., 1927. - Package bees north and south. A mer. Bee J. 67 (3) : 128-129.

EGgers M. E., 1933. - Feeder for package bees. Glean. Bee Cult. 61 (3) : 162-163.

Komarow P. M. and Alpatov W. W., 1935. - Die Einfluss von Futter und Alter auf den Aufenthalt der Biene ausserhalb des Stockes. Archive für Bienened XVI (4/5) : 131-151. Reviewed in Bee World 16 (10) : 117-118.

MCDougall M., 1936. - Trucking package bees without feeder tins. Amer. Bee J. 76 (4) : 184.

Menashes S., 1971. - The mailing of package bees. Amer. Bee J. 111 (3) : 96-97. 